\title{
Political pains
}

Daniel S. Greenberg

The Mortal Presidency: IIIness and Anguish in the White House. By Robert E. Gilbert. Basic Books: 1992. Pp. 314. \$25.

PRESIDENTIAL health is a deep concern of the electorate in health-obsessed America - so deep, in fact, that incumbents and candidates frequently lie about their infirmities, often in connivance with their personal physicians. The appearance of ruddy good health, symbolized by sweat-soaked jogging or at least an afternoon of golf, is a main ingredient of political success at the presidential level. But the facts of presidential health often belie the appearances.

While under treatment for chronic, debilitating Addison's disease, John F. Kennedy vigorously denied that he suffered from the affliction. His doctors fended off the press with a variety of obfuscations. Franklin Roosevelt, in terminal decline after 12 years in office, concealed his physical decrepitude, won reelection and died 6 months later. Dwight Eisenhower suffered a heart attack and a stroke and underwent abdominal surgery during his two terms in the White House. Often weak and unable to function in the aftermath of these tribulations, Eisenhower was nonetheless depicted by his physicians and public-relations managers as the beneficiary of extraordinary recuperative powers - and the public believed them. In a footnote to the 1992 presidential election, former senator Paul Tsongas, diagnosed in late November with a recurrence of cancer, admitted that during his unsuccessful run for the Democratic nomination, he had not been fully candid about his health.

The rigours of the office, presidential infirmity and medical deception are the subject of The Mortal Presidency. Robert E. Gilbert, professor of political science at Northeastern University, turns in an excellent performance in demonstrating that health and politics American-style are an uncertain and troublesome combination. But along with many others who have delved into the elusive problems of anticipating and coping with presidential frailties, Gilbert is at a loss to offer feasible remedies beyond measures now in place.

The bulk of the book is devoted to the health histories of five presidents of this century - Coolidge, who fell into depression after the death of his young son; Roosevelt, Eisenhower and Kennedy, with their aforementioned ailments, plus others; and Reagan, who survived a gunshot wound and colon cancer, while his handlers followed the well-established practice of assuring the public that the chief was improving at an incredible pace. Gilbert writes that following Reagan's cancer surgery, "[t]he release of photographs was ... con-

\section{IMAGE UNAVAILABLE FOR COPYRIGHT REASONS}

trolled and arranged for maximum political effect. [Presidential Press Secretary] Speakes describes the first post-operative photograph of the President as being 'artfully arranged to conceal the nasogastric tube that had been inserted in Reagan's nose and was held in place by tape.' The photograph showed the First Lady kissing the President, with her face concealing both tape and tube."

By custom and constitutional amendment, the American political system has tried to reduce the uncertainties of presidential disability. Although there is no means of compelling candidates to present themselves to independent medical panels, custom - and the threat of worrisome speculation - assures the public release of detailed medical records and, invariably, clean bills of health from the candidates' physicians. During the presidential campaign, Bill Clinton quickly produced his medical records when the New York Times reported that he had been less forthcoming about his medical status than other

candidates of recent times.

Adopted in 1967 to reduce uncertainties in presidential succession, the 25th Amendment to the Constitution has left a good deal of unease about the passage of power in the nation's greatest office, especially in the foggy circumstances of temporary presidential disability. After labouring long on the amendment, Senator Birch Bayh conceded to his colleagues, "I have never pretended ... that it would cover every possible, conceivable contingency that the mind of man could contrive. I have suggested that it is the best thing that we have been able to come up [with], and it is so much better than anything we have ever had before - namely, nothing." Gilbert agrees with that modest appraisal, stating that the amendment "probably does the best that can be expected" and that "tinkering with it would be unwise."

While health is a sensitive issue in American presidential politics, it is by no means certain that unrestrained medical candour would improve the selection process. Some very sickly people, Kennedy among them. have successfully managed the rigours of the presidency. Furthermore, the predictive powers of medicine do not reliably extend to political performance. What is the electorate to conclude if informed that a candidate suffers from this or that dreadfulsounding disease? When doctors disagree, how can voters decide?

In his principal venture into reform. Gilbert observes that insufficient attention is paid to the mental health of presidents. To

correct this, he suggests that "a small mental health unit might be established in every administration as part of the White House medical office to assist the White House physician in diagnosing and treating psychological problems."

The medical desirability of this innovation is indisputable - as is the political impossibility. It should be recalled that in 1972 Senator Thomas Eagleton, candidate for vice-president, was dropped from the Democratic ticket after it was disclosed that he had been treated for depression. In the 1988 presidential election, Michael Dukakis, the Democratic candidate, went to great lengths to dispel scurrilous rumours that he had once consulted a psychiatrist.

When it comes to the presidency, Americans apparently feel that it is better to be disturbed than treated.

Daniel S. Greenberg is editor and publisher of Science and Government Report, 3736 Kanawha Street NW, Washington, DC, 20015, USA. 